\title{
A SZOLGÁLTATÁSOK OSZTÁLYOZÁSA ÉS SZEREPÜK A REGIONÁLIS FEJLŐDÉSBEN
}

\author{
(The classification of the service sector and it's role in the regional \\ development)
}

\section{RAFFAY ZOLTÁN}

Igen sokáig egyes társadalomtudományok, de a közvélemény - ideszámítva a politikusokat és a médiát - is abban a hitben élt, hogy a termelés kizárólag mezőgazdasági és feldolgozóipari árutermelést jelent. A gazdaság rendszerének eme megközelítése helyett csak lassan nyer teret a nyugati társadalmakban a jelenkor gazdaságának valósághủbb szemlélete, amelyben a szolgáltatások (vagy másképpen a tercier szektor) a teljes termelésből és foglalkoztatásból mintegy kétharmados arányban részesednek - és ez az arány továbbra is egyre növekszik (1. táblázat).

\section{TÁBLÁZAT}

A szolgáltató szektor részesedése az aktív népességen belül az OECD országokban, 1966$1989(\%)$

(The share of the service sector inside the active people, in the OECD, 1966-1989)

\begin{tabular}{|lcccccc|}
\hline & 1966 & 1970 & 1975 & 1980 & 1985 & 1989 \\
\hline Kanada & 57.5 & 61.4 & 64.6 & 66.0 & 69.5 & 70.1 \\
USA & 58.3 & 61.1 & 65.3 & 65.9 & 68.8 & 70.5 \\
Észak-Amerika & 58.2 & 61.1 & 65.2 & 65.9 & 68.9 & 70.4 \\
Japán & 45.1 & 46.9 & 51.5 & 54.2 & 56.4 & 58.2 \\
Ausztrália & 53.3 & 55.0 & 59.4 & 62.4 & 66.2 & 68.0 \\
Új-Zéland & 48.1 & 48.6 & 53.5 & 55.4 & 56.5 & 64.3 \\
Ausztria & 41.1 & 44.0 & 46.6 & 49.3 & 52.9 & 55.1 \\
Belgium & 49.2 & 52.5 & 56.5 & 62.1 & 66.7 & 68.7 \\
Dánia & 48.6 & 50.7 & 58.8 & 62.4 & 65.2 & 66.9 \\
Finnország & 38.3 & 42.8 & 49.0 & 51.8 & 56.5 & 60.2 \\
Franciaország & 43.9 & 47.2 & 51.1 & 55.4 & 60.4 & 63.5 \\
NSZK & 41.3 & 42.9 & 47.6 & 51.0 & 54.5 & 56.5 \\
Görögország & 30.4 & 34.2 & 36.8 & 39.5 & 43.7 & 47.1 \\
Izland & 45.5 & 46.9 & 49.5 & 51.4 & 55.8 & 59.2 \\
İrország & 40.7 & 43.1 & 45.8 & 49.2 & 55.2 & 56.5 \\
Olaszország & 37.8 & 40.3 & 44.1 & 47.8 & 55.2 & 58.2 \\
Luxemburg & 41.6 & 46.3 & 49.6 & 56.6 & 61.9 & 65.4 \\
Hollandia & 52.1 & 54.9 & 59.4 & 63.6 & 67.0 & 68.8 \\
Norvégia & 46.5 & 48.8 & 56.1 & 61.9 & 65.4 & 68.1 \\
Portugália & 30.9 & 37.1 & 32.3 & 36.1 & 42.2 & 45.7 \\
Spanyolország & 35.7 & 37.4 & 39.6 & 44.6 & 49.9 & 54.0 \\
Svédország & 48.3 & 53.5 & 57.1 & 62.2 & 65.3 & 67.0 \\
Svájic & 42.1 & 45.4 & 50.2 & 55.0 & 48.3 & 59.3 \\
Tórökország & 17.5 & 17.9 & 21.3 & 26.2 & 27.7 & 29.5 \\
Egyesült Királyság & 50.0 & 52.0 & 56.8 & 59.7 & 65.8 & 68.4 \\
OECD.Európa & 40.5 & 42.9 & 46.6 & 50.6 & 55.0 & 57.6 \\
EGK & 42.6 & 45.0 & 48.9 & 52.7 & 57.8 & 60.7 \\
\hline OECD összesen & 46.6 & 49.3 & 53.5 & 56.6 & 60.3 & 62.5 \\
\hline
\end{tabular}

Forrás: Soy, 1994. 274. o. 
A klasszikus nézet szerint a szolgáltatások nem játszanak jelentös szerepet a gazdaságban, nem hoznak létre új értéket, hanem parazitaként felélik a más szektorokban megtermelt értékeket. Századunk harmincas éveitöl azonban kezdtek felfigyelni arra, hogy amint egy társadalom gazdagodik, egyre többet költ szolgáltatásokra és az ủj munkahelyek egyre nagyobb részben a tercier szektorban jönnek létre, nem pedig a hagyományos feldolgozóipari szektorban. Az 1970-es évek elején, a jóléti társadalmak megjelenésével Bell (1973) már a „posztindusztriális társadalom” eljöveteléröl beszél, ahol a legnagyobb gazdasági szektor az egészségügyi, rekreációs, oktatási és kulturális szolgáltatások ${ }^{1}$.

Bell nézetei nem találtak széles körben elfogadásra. Ellenzői (Baumol, Skolka és Gershuny) azzal érveltek, hogy a szolgáltató szektorban a munkaerö termelékenységének növekedése semmiképpen sem érheti el a többi szektorban tapasztalható szintet (ennek legfontosabb okát abban látták, hogy a szolgáltatások elóállítóinak és fogyasztóinak térben egymás közelében kell lenniük). Baumol és Kaldor egyenesen káros jelenségnek tartotta a nyugati társadalmakban erősödỏ dezindusztrializációs folyamatot: véleményük szerint az alacsony termelékenységü szolgáltató tevékenységek terjedése lelassítja, sỏt megállítja a gazdaság növekedését. Mivel az alacsony termelékenység miatt a szolgáltatásokat igen magas áron tudják csak elóálítani a formális gazdaságban, az emberek inkább a háztartásokon belül, saját maguk állítják elő őket (Skolka és Gershuny véleménye szerint), így a szolgáltató társadalom helyett helyesebb „önkiszolgáló társadalomról” beszélni (Illeris 1989).

A szolgáltatások kutatása az 1980-as évekig szinte kizárólag a végsỏ fogyasztók, a háztartások számára kínált szolgáltatások vizsgálatára szorítkozott (amelyek az összes megtermelt szolgáltatás legnagyobb részét teszik ki), az évtized második felében azonban a figyelem egyre inkább a termelỏ szolgáltatások felé fordult: azon „köztes” szolgáltatások felé, amelyeket mind az árutermelésben, mind a fogyasztói szolgáltatások elő́llításában felhasználnak. A nyugati társadalmakban jelenleg a termeló szolgáltatások az a szektor, amely növekedése meghaladja az összes többi ágazatét. Amint a termeló vállalatok áttérnek a fordista típusú tömegtermelésröl, a szabványosított javak elóállításáról a különböző piaci szegmensek gyorsan változó keresletét kielégíteni képes, testreszabott, rugalmasabb termelésre, szükségszerüen és rendkívüli mértékben megnött a $\mathrm{K}+\mathrm{F}$, a képzés, oktatás, vállalatirányitás, tervezés és marketing-tevékenységek jelentősége a termelési folyamatban. A posztfordista társadalmakban a termelö szolgáltatások kulcsfontosságú szektorrá váltak.

\section{A szolgáltatások meghatározása}

A Magyar Értelmező Kéziszótárban a következỏ definíciót olvashatunk a „szolgáltatás” címszó alatt:

„Szolgáltatás: ... 2. A lakosság szilikségleteit kielégítö, de új terméket létre nem hozó gazdasági tevékenység" (Magyar Értelmezó Kéziszótár 1982).

Számos magyar közgazdasági és egyéb szakszótár (Gazdaságpolitikai Kisszótár 1966, 1976, 1983, Közgazdasági ABC 1973, Közgazdasági ABC mezögazdáknak 1967, Közgazdasági Kislexikon 1987, Világgazdasági Kisszótár 1994) a szolgáltatások azon tulajdonságát emeli ki, miszerint olyan társadalmilag rendszeresen kifejtett tevékenységek, amelyek új anyagi termékeket nem hoznak létre, de azok hasznạlati értékét helyreállítják vagy növelik, elóálításukat, felhasználásukat, fogyasztásukat közvetlenül vagy közvetve 
megkönnyítik. Kiemelik továbbá, hogy a tevékenység folyamata és felhasználása időben és térben egybeesik. (A szolgáltatások ágazati bontásánál azonban már nem minden esetben azonos a véleményük.)

A „szolgáltatás" szó angol és francia megfelelője, a ,service" a latin ,servus = szolga" szóból ered. Illeris (1989) négy jelentését sorolja fel:

1. segítség, haszon, elöny, használat,

2. nem anyagi természetü termék, .

3. olyan eszköz, amelyet egy szolgáltatás eloállításakor felhasználnak,

4. maga a szolgáltatás tevékenysége: olyan munka, amely során szolgáltatás jön létre.

A Longman Dictionary of Business English a „szolgáltatás” szó második jelentéseként a következőt írja: „rendszeres ellátás valamivel, ami segíti a közösséget, és közigényt elégít ki".

A Macmillan Dictionary of Modern Economics (Modern Közgazdaságtan Ismerettára) címủ kötetben a szolgáltatások közgazdasági megközelítésével találkozunk. Eszerint „közgazdasági értelemben szolgáltatás minden olyan funkció vagy feladat, amelyet végrehajtanak és amelyre létezik kereslet és így van ára. Időnként úgy hivatkoznak rájuk, mint a nem fizikai javakra; egyik jellegzetességük, hogy a termelés helyén fogyasztják el. Általában nem szállíthatók, így ellenállnak az arbitrázsnak abban az értelemben, hogy nem lehet a szolgáltatást valahol megvenni, majd egy másik áron máshol továbbadni."

A hétköznapi életben a ,szolgáltatás" fogalmán szinte kizárólag olyan tevékenységeket értünk, amelyek életủnket könnyebbé, kellemesebbé teszik: a javító- és tisztító tevékenységet, a fodrászt stb., azaz a szolgáltatások „klasszikus” formáit, a személyes és háztartási szolgáltatásokat.

\section{A szolgáltatások jellemzöi}

A hagyományos termékekkel összehasonlítva, a szolgáltatásoknak számos olyan jellemző tulajdonságuk van, amelyek alapján különböznek a mezőgazdaság vagy ipar által elóállított cikkektől. Ezek a következők:

- Egy szolgáltatás elóállítása és elfogyasztása általában egy időben történik, nem lehetséges a szolgáltatásokat tárolni vagy birtokolni;

- A mezőgazdasággal és az iparral összehasonlítva nem termelékeny (Adam Smith és Karl Marx nézete szerint): csak használati értéke lehet, de hozzáadott értéke nem, így nem járulhat hozzá a tỏkefelhalmozáshoz ${ }^{2}$;

- A fogyasztó aktívan részt vesz a termék előallításának folyamatában (kivéve a tisztán közősségi szolgáltatásokat és egyes információs szolgáltatásokat);

- Munkaerő-intenziv (mára azonban a szolgáltatások jelentős része tókeintenzivvé vált);

- Általában korlátozott mértékben érvényesülnek csak a méretgazdaságossággal járó elönyök;

- Fontos és szükséges a fogyasztóval való személyes kapcsolattartás (amely a közlekedési és távközlési infrastruktúra alacsonyabb fejlettségi szintjein egyben a fogyasztóhoz való térbeli közelség szükségességét is jelentette);

- A szolgáltató tevékenységek elönyben részesítik a „központi helyeket”;

- Magas a jövedelemrugalmasságuk;

- Általában „fehérgalléros”, képzett munkaerőt igénylö, viszonylag stabil feltételeket biztosító munkahelyek. 
Vannak bizonyos termékek vagy tevékenységek, amelyek határeseteket jelentenek a szekunder és tercier tevékenységek között. Ilyenek például:

- a közmüvek, amelyek Európában a szekunder, míg Észak-Amerikában a tercier szektorba tartoznak,

- olyan tevékenységek, amelyek alapvetöen a szekunder szektor részei, de javító, karbantartó munkákat is végeznek (pl. építöipar),

- a különbözö hordozókon (pl. CD-n, mágneslemezen, kazettán, papíron stb.) tárolt információs szolgáltatások: ezek nem tipikus szolgáltatások abból a szempontból, hogy a fogyasztó nem vesz részt elóállításukban, hanem a kész terméket fogyasztja el, továbbá az információhordozók tárolhatók és birtokolhatók is; szolgáltatásnak amiatt tekinthetők, hogy információtartalmuk sokkal fontosabb és értékesebb, mint tárgyi megjelenésük,

- a lízing- és bérbeadási tevékenységek,

- kreatív jellegủ, kézzelfogható terméket elóállító tevékenységek (pl. szobrászat, festészet stb.).

Számos esetben egyre inkább elmosódik a termékek és szolgáltatások közötti különbség. Elég, ha a tömegkommunikációra vagy például az éttermekre gondolunk: mindkét esetben egy bizonyos terméket vásárolunk, amelynek létrehozásában azonban a belefektetett tudás, információ sokkal fontosabb, mint maga a termék fizikai mivoltában. Az értékesebb fogyasztási cikkeket egyre inkább bizonyos szolgáltatásokkal együtt, csomagként értékesítik: pl. a számítástechnikában a hardvereket általában szoftverekkel együtt, csomagként kaphatjuk meg; az autószalonban kiválasztott gépkocsi karbantartásában, javitásában, szervizelésében (már maga a szó is szolgáltatást jelent!) a kereskedỏ az értékesítés után is segitségünkre lesz.

\section{A szolgáltató tevékenységek osztályozása}

Alapvetően kétféle osztályozást különböztethetünk meg, a szolgáltatások ágazati és foglalkozás szerinti besorolását. Mindkettőn belül számos felosztás lehetséges, az alapul szolgáló kritériumoknak megfelelően. Végül egy új szempont szerint történỏ osztályozást mutatok be, (Illeris 1989) alapján.

\section{A szolgáltatások ágazatok szerinti osztályozása}

Alapul általában a NACE (Nomenclature des Activités dans le Communautés Europénnes) vagy az ISIC (International Standard Industrial Classification) szolgál. Az osztályozás, amely jelen esetben a tevékenység fö outputja, vagy eredménye szerint történik, a következö:

- nagy- és kiskereskedelem, szállodák és éttermek, javítási tevékenységek;

- közlekedés és hírközlés;

- pénzügyi, biztositási, ủzleti szolgáltatások, bérbeadás;

- egyéb szolgáltatások: közigazgatás és védelem, higiéniai szolgáltatások és takarítás, oktatás és kutatás, egészségügyi és szociális szolgáltatások, szervezetek, szórakoztató és kulturális szolgáltatások, valamint személyes és háztartási szolgáltatások.

Szintén az outputot veszi figyelembe az az osztályozás, amely a termelékenységet méri és Gadrey nevéhez füzödik. 
Katouzian a gazdasági fejlettség alapján osztályozott: eszerint léteznek kiegészitó szolgáltatások (pénzügy, közlekedés és szállitás, nagy- és kiskereskedelem stb.), „új szolgáltatások" (oktatás, egészségügy, szórakoztató és kulturális szolgáltatások, szállodák es éttermek stb.) és ,"régi szolgáltatások" (háztartási és személyes szolgáltatások).

Ennek az osztályozásnak a továbbfejlesztett változata Browning és Singelmann besorolása, amelynek alapja a gazdaságban betöltött funkció és a felhasználó szektor. Különbséget tesznek így elosztási szolgáltatások, termelö szolgáltatások, szociális szolgáltatások és személyes szolgáltatások között. Hasonló megközelítésre épül Noyelle és Stanback rendszere is.

A felhasználó szektor szerint a következöképpen osztályozhatók: termelö szolgáltatások és háztartási szolgáltatások, illetve van egy harmadik kategória, amelybe a „szükséges rossznak" tekintett közlekedés és kereskedelem, illetve a „tisztán közösségi \$zolgáltatások"': az igazságügy, a rendörség és a védelem kerülnek.

Boulianne és Thévoz osztályozása a gazdaság egészében vagy a termelési rendszerben betöltött szerepre alapul. Ennek megfelelóen forgalmazási, elosztási és szabályozási \$zolgáltatásokat különböztettek meg.

Széles körben elterjedt osztályozási formák továbbá azok, amelyek a tulajdonforma (állami vagy privát) vagy a piaci viszonyok (piacon értékesített vagy sem) szerint különböztetik meg a szolgáltatásokat.

Érdemes megemlíteni a telephelyelmélet és a "gazdasági alap modell" megközelítését. A telephelyelmélet és a "gazdasági alap modell" alapvetỏ és nem alapvetỏ tevékenységeket különböztetett meg egymástól. Az alapvető tevékenységek körébe azok tartoznak, amelyek az adott régióból termékeket exportáltak, míg a nem alapvetö tevékenységek ezeket szolgálják ki. Mivel a gazdasági fejlettség alacsonyabb fokán a szolgáltatások sokáig nem nélkuilözhették a személyes kapcsolattartást a termelö és a fogyasztó között, a szállítási költségek pedig viszonylag magasak voltak, a szolgáltatásokat csak az adott régión belul tudták értékesíteni, igy azok nem voltak alapvető tevékenységnek tekinthetők. Mára ez a nézet az eredeti formájában nem állja meg a helyét: a technika (elsősorban számitástechnika) fejlödésével egyre könnyebb szolgáltatásokat exportálni, különösen az egyszerủbb, szabványositható szolgáltató revékenységek termékeit. A szolgáltatások közül így egyre több bekerül az „alapvető tevékenységek" kategóriába (Illeris 1996).

A szolgáltatások foglalkozás szerinti osztályozása

A szolgáltatások e szempont szerint történó osztályozására ez idáig kevesebb figyelmet fordítottak, mint az ágazati osztályozásra. Alapul szolgálhat erre az ISCO (International Standard Classification of Occupations).

Számos kutató (például Johnstad) a termelési rendszerben betöltött szerepből kiindulva a következöképpen osztja fel a szolgáltató tevékenységeket:

- elosztási szolgáltatások: szállitás, távközlés és kereskedelem;

- információs munkák: közigazgatás, kutatás és müvészetek, irodai munka stb.;

- újratermelés: egészségügy és szociális szolgáltatások.

Boulianne és Thévoz a termelö vállalatok funkcionális vizsgálatából indult ki, így különbséget tesznek $\mathrm{K}+\mathrm{F}$, beszállitás és tárolás, szervezés, irányitás, karbantartás és értékesítés között. 
Gottmann nevéhez füződik a kvaterner szektor fogalmának bevezetése. Célja az volt, hogy elkülönítse a gyors létszámnövekedést mutató nagyvárosi tevékenységeket. Abler és Adams ennek továbbfejlesztése során a gazdasági tevékenységeket öt szektorra osztotta fel, amelyek közül három szolgáltató ágazat: a tercier szektor, amely kézzelfogható termékekkel kapcsolatos szolgáltatásokat állit elő (szállítás és közlekedés, javitás), a kvaterner szektor, amely a rutinszerủen elóállítható információk nagy tömegủ termelését végzi: pénzügy, biztosítás stb., és végül a kviner szektor, amely feladata a nem rutinszerü, hanem testreszabott információ elóállitása és a döntéshozatal: ilyen a kormányok tevékenysége.

Az osztályozás alapja a tevékenység tárgya is lehet. E szerint áruról, információról vagy személyekról beszélhetünk. Hill erre építi fel osztályozási rendszerét és

- termékekkel foglalkozó szolgáltatásokat (amelyek a termékek állapotát változtatják meg);

- személyekkel foglalkozó és végül

- tisztán közösségi szolgáltatásokat különböztet meg.

Hasonló megközelítésen alapszik a szolgáltatásoknak az a felosztása is, amely Illeris (1996) nevéhez füződik. Ez az osztályozás nemcsak újszerúsége és szintetizáló jellege miatt érdemel különös figyelmet, hanem azért is, mert gyakorlati tapasztalatokra épülve, a leginkább alkalmazkodik a modern társadalmak gazdaságához.

Illeris osztályozása a következöképpen néz ki:

A) Termékekkel kapcsolatos szolgáltatások (ember-termék kapcsolat)

1. egyedi termelés (tisztítás, karbantartás, javítás, szállodák és éttermek, kölcsönzés)

2. szabványtermelés (elosztási szolgáltatások: áruszállitás, raktározás, kis- és nagykereskedelem)

B) Információs szolgáltatások (ember-jelkép kapcsolat)

1. egyedi termelés (kvaterner szolgáltatások: vállalatvezetés, felsőszintủ irányitás, kutatás, tanácsadás, mủvészetek, szórakoztatás, tömegkommunikáció és szoftverek elöállítása, stratégiai jelentőségủ banki és biztosítási tevékenység, közigazgatás, ágazati szervezetek)

2. szabványtermelés: rutinszerủ adminisztráció és alsó szintủ irányítás, távközlés, rutinszerüen végzett számítástechnikai szolgáltatások, pénzügyi és biztositási szolgáltatások

C) Személyekhez kötődoó szolgáltatások (ember-ember kapcsolat)

1. egyedi termelés: oktatás, egészségügy, testápolás, sport, gyermekek, sérültek és idősek gondozása

2. szabványtermelés: tömegközlekedés

D) Társadalmi biztonsági szolgáltatások: rendörség, védelem

$\mathrm{Az} \mathrm{A} 1, \mathrm{Bl}$ és $\mathrm{Cl}$, azaz az egyedi, testreszabott termelés esetében a termelékenység csak korlátozott mértékben növekedhet. Ennek hatásai különbözỏek lehetnek: vagy egyre inkább háztartásokon, illetve vállalatokon belül állítják elö azokat, vagy növekszik a karbantartást nem igénylö, egyszer használatos termékek felhasználása, ha pedig ezen megoldások egyike sem alkalmazható, növekszik a foglalkoztatottak létszáma e szektorokban.

Az A2, B2, C2, azaz a szabványosított, tömegszerủen végezhető tevékenységek területén nagyobb lehetőségek mutatkoznak a termelékenység növelésére, ennek következtében az itt alkalmazottak száma stagnál vagy csökken. 
Gyakorlati tapasztalatok (pl. az Egyesült Királyságban) is alátámasztják mindezt: az uzleti szolgáltatások, vállalatirányítási tanácsadás, reklámtevékenység stb. a szolgáltatásokon belül a legdinamikusabban növekvő szektor az alkalmazottak számát tekintve, tehát azok a tevékenységek, amelyek nem végezhetőek rutinszerüen, hanem testreszabott, egyedi megoldásokat kínálnak (2. táblázat).

\section{TÁBLÁZAT}

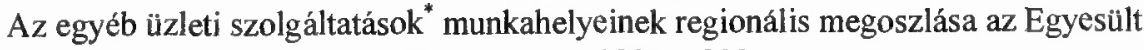
Királyságban, 1981-1989

(The regional disparities of the working places in "other business services" sector in the U.K., 1981-1989)

\begin{tabular}{|c|c|c|c|c|c|c|}
\hline \multirow[t]{2}{*}{ Régió } & \multicolumn{2}{|c|}{1981} & \multicolumn{2}{|c|}{1989} & \multicolumn{2}{|c|}{ Változás 1981-1989 között } \\
\hline & $f o ̈$ & $\%$ & $f o$ & $\%$ & fó & $\%$ \\
\hline Nagy London & 54477 & 40,9 & 133940 & 37,0 & 79463 & 146 \\
\hline Délkelet többi része & 23832 & 17,9 & 78634 & 21,8 & 54802 & 230 \\
\hline Kelet-Anglia & 2156 & 1,6 & 7557 & 2,1 & 5401 & 251 \\
\hline Délnyugat & 5621 & 4,2 & 20132 & 5,6 & 14511 & 258 \\
\hline Kelet-Midlands & 4151 & 3,1 & 13639 & 3,8 & 9488 & 229 \\
\hline Nyugat-Midlands & 11299 & 8,5 & 23630 & 6,5 & 12331 & 109 \\
\hline Eszaknyugat & 10619 & 8,0 & 29479 & 8,2 & 18860 & 178 \\
\hline Yorks és Humberside & 5514 & 4,1 & 17852 & 4,9 & 12338 & 224 \\
\hline szak & 3181 & 2,4 & 7251 & 2,0 & 4070 & 128 \\
\hline Wales & 2473 & 1,9 & 6323 & 1,7 & 3850 & 156 \\
\hline Skócia & 8269 & 6,2 & 20289 & 5,6 & 12020 & 145 \\
\hline Eszak-Írország & 1630 & 1,2 & 2924 & 0,8 & 1294 & 79 \\
\hline Eyesult Királyság & 133222 & 100 & 361650 & 100 & 228428 & 171 \\
\hline
\end{tabular}

Megjegyzés: A munkahelyek száma föállásokban értendó, a részmunkaidōs állásokat a fỏállások 0,5 szeresének lekintve

* - Az „egyéb üzleti szolgáltatások" kategóriába a reklámtevékenység és az üzleti szolgáltatások tartoznak a brit Department of Employment negyedévenként közzétett munkaügyi statisztikáiban.

Forrás: Bryson-Keeble - Wood 1993. 120. o.

\section{A szolgáltatások szerepe a regionális fejlödésben}

A szolgáltatások növekedésének legjelentösebb okai az egy före esö jövedelem növekedése következtében a szolgáltatások iránti kereslet élénkülése és ennek a keresletnek a fogyasztási javakhoz viszonyított nagyobb relatív rugalmassága, valamint az állami és non-profit szektor növekvő jelentősége. Emellett a nyugati társadalmakban tanúi lehetünk a termelési tevékenységek strukturális átalakulásának is: az ipari termelés és a \$zolgáltatások egyre erősödő integrációjának.

Jelentős változás viszont, hogy míg a gazdasági fejlödés korábbi szakaszaiban a hagyományos szektorok generálták a szolgáltatásokat, mára a tudásigényes szolgáltatások indukálnak sikeres vállalkozásokat a primer, illetve szekunder szektorban. Ez a súlyponteltolódás azonban korántsem szerepcsereként értelmezhetó, hiszen bár a \$zolgáltatások az a szektor, amely a gazdaságilag fejlett országokban a munkaerỏ legnagyobb részét foglalkoztatja és a legdinamikusabb növekedést mutatja, még mindig az pari termékek elóllítása jelenti a gazdasági növekedés motorját. Inkább arról van szó, 
hogy a szolgáltatások, - elsősorban az üzleti szolgáltatások - a termelő tevékenységek, vállalkozások számára létfontosságúvá, a versenyképességet alapvetően meghatározó tényezővé váltak. Az erősödő munkamegosztás következtében a termelési ciklus egyre inkább elkülönülö fázisokra bomlik: a termékfejlesztés, szervezés, irányítás, ellenőrzés, maga a termelés és végül az értékesités fázisaira (Soy 1994). Az öt funkcióból négy tisztán szolgáltató jellegú.

A szolgáltatások iránti fokozódó igényt a vállalatok vagy saját szervezetükön belülröl, vagy önálló, specializált szolgáltató szervezetek igénybevételével elégítik ki. Mindkét megoldás sajátos előnyökkel jár: a belső üzleti szolgáltatások vagy „implicit tercier szektor" segítségével elkerülhetök a tranzakciós költségek, a döntéshez szükséges információk rendelkezésre állnak, erősödhet a vállalaton belüli szinergia; külső szolgáltatások igénybevétele mellett a méretgazdaságosság szól olyan esetekben, amikor egy bizonyos szolgáltatást, speciális jellegéből adódóan, a termelő vállalat saját keretein belül nem képes gazdaságosan elóállítani.

A termelő szolgáltatások „internalizációját” (azaz saját szervezeten belüli, belső elóállítását) vagy „externalizációját” (azaz piacon történő külső beszerzését) számos tényezö befolyásolja. A legfontosabbak ezek közül:

- A szolgáltatások specializálódása általában az externalizációt, míg szabványosításuk az internalizációt erősíti;

- Egyes szolgáltatások alkalmazásának gyakorisága nagyban befolyásolja, hogy a vállalat azt belülről vagy kívülrỏl szerzi-e be;

- Bizonyos stratégiai jellegủ funkciókat és információkat a vállalatok nem szívesen engednek ki ellenörzésük alól, ez a tényezö, valamint a kockázat csökkentésének igénye a szolgáltatások saját szervezeten belül történỏ előallítása mellett szól;

- Igen fontos kérdés, hogy bizonyos szolgáltatások beszerezhetőek-e a helyi piacon;

- Az internalizációs folyamatot erősíti, hogy a vállalat rendelkezésére álló munkaerỏ rugalmasabban és hatékonyabban hasznositható, ezáltal csökkennek a termelés költségei, a kibocsátás pedig növekszik.

Általában elmondható, hogy a vállalatok a szolgáltatások saját szervezeten belüli elöállitását akkor preferálják, ha a koordináció költségei alacsonyabbak a tranzakciós költségeknél, azok kívülről történő beszerzését pedig akkor, ha a speciális szolgáltatásokat nyújtó önálló cégek szaktudása, rugalmassága, hatékonysága meghaladja a vállalaton belül elöállított szolgáltatásokét.

Lényeges emellett a szolgáltatásokat igénybe vevő vállalatok mérete is: egy nagyvállalat lényegesen többféle szolgáltatást tud gazdaságosan maga előallítani, mint a kis- és középvállalatok, amelyek fủggése a külső szolgáltató cégektől sokkal erősebb.

Az egyes régiók gazdasági aktorai közötti kohéziót természetesen elsősorban a szolgáltatások külső beszerzése, a termelő és szolgáltató cégek fokozott együttmüködése erősíti. Befektetőket, üzleti szereplőket leginkább olyan térség képes vonzani, amely hozzá tud járulni a hatékony üzleti múködéshez. A termelö vállalatok és szolgáltató cégek erősődỏ és célirányos integrációja egyrészt az egymással szoros kapcsolatban lévő vállalkozások gazdasági szereplésének javulásához vezethet a régión belül, másrészt a régió egészének interregionális vagy akár nemzetközi versenyképességét kedvezően befolyásolhatja (Cappellin 1995).

Természetesen nem csak a termelő vagy üzleti szolgáltatások gyakorolnak hatást a régiók gazdasági szereplésére. A modern termelési rendszerekben egyre fontosabb 
termelési tényezóvé váló emberi eröforrások számára a vonzó lakókörnyezet mind nagyobb jelentőségre tesz szert a letelepedési döntések során. A vonzó környezet nemcsak tájképi szépséget, tiszta és viszonylag érintetlen természeti környezetet jelent, hanem kulturális és kényelmi szempontból is attraktív miliőt. A fejlett infrastruktúra mellett az oktatási, kulturális, egészségügyi, szabadidős stb. szolgáltatások is fontos vonzó tényezőket jelentenek, szerepük rendkívül fontos a munkaerö, a szellemi erőforrások újratermelésében is.

A szolgáltatások más módon is befolyásolják a regionális fejlődés alakulását, melynek alapja a szolgáltatásoknak az a tulajdonsága, hogy elönyben részesítik (különösen a legfejlettebb üzleti szolgáltatások) az urbánus, nagyvárosi környezetet, ahol az agglomerációs előnyöket ki tudják használni (Illeris 1994; Senn 1994). Ezáltal egyrészt könnyen konzerválhatják a meglévő regionális különbségeket: multiplikátor hatásuknál fogva nagyban elösegítik telephelyük régiójának gazdasági fejlödését, és így még vonzóbb gazdasági-társadalmi kömyezetet teremtenek. A hátrányosabb helyzetủ régiók viszont, amelyek nem képesek fejlett tercier tevékenységeket vonzani, még jobban leszakadhatnak a fejlettebb területektöl. Erösödik a régiók közötti polarizáció, másfelól viszont a felzárkózás lehetséges útját mutatják a kevésbé kedvező helyzetben lévő régiók számára. Ehhez a fejlett közlekedési és telekommunikációs infrastruktúra kiépülése kedvezó hátteret teremthet.

Általában a településhierarchia alsó fokain álló településeken kevésbé jellemző a fejlett termelö, üzleti szolgáltatások jelenléte, a tercier szektor itt többnyire a háztartási és személyes szolgáltatásokra szorítkozik. Nagyobb és funkcionális tekintetben jelentösebb településeken már megjelennek az alapvetỏ üzleti szolgáltatások is, mint könyvelés, adótanácsadás stb., de általában csak a helyi piac kiszolgálására. A specializáltabb, nagyobb szaktudást és piacot igénylő szolgáltatások általában a városi, jellemzően a nagyvárosi környezetet keresik, és ügyfeleik közül számosan gyakran a régión kívüli területekről kerülnek ki. Ezzel egyre nagyobb mértékben járulnak hozzá a régió exportjához.

A regionális gazdaságra gyakorolt kedvező hatásai mellett e folyamatnak is megvannak a maga veszélyei. A nagyobb, magukat a településhierarchia több szintjén is képviseltető szolgáltató cégek általában stratégiai jelentóségú döntéseiket a kơzpontban hozzák és legjövedelmezőbb profilú vállalkozásaikat is ott tartják, a kisebb településeknek és a perifériáknak a kevésbé jövedelmezó tevékenységeket hagyva csak. Ez a szürö-modell múködik ma Magyarországon is: a központi régió „megszüri” a legértékesebb szolgáltató (de nemcsak a szolgáltató) tevékenységeket, a perifériákra irányítva a hagyományos és kevésbé jövedelmező ágakat. Ez a periferikus helyzetủ régiókban átmeneti eredményeket ugyan hozhat, de hosszú távon az elmaradott gazdaságszerkezet konzerválásával a perifériák felzárkózási esélyeit nagyban gyengíti (Horváth 1994) (1., 2. ábra). 


\section{1. ÁBRA}

A szolgáltatások aránya a foglalkoztatottak összlétszámán belül Magyrország megyéiben (\%)

(The share of service sector from the active workers by counties, \%)

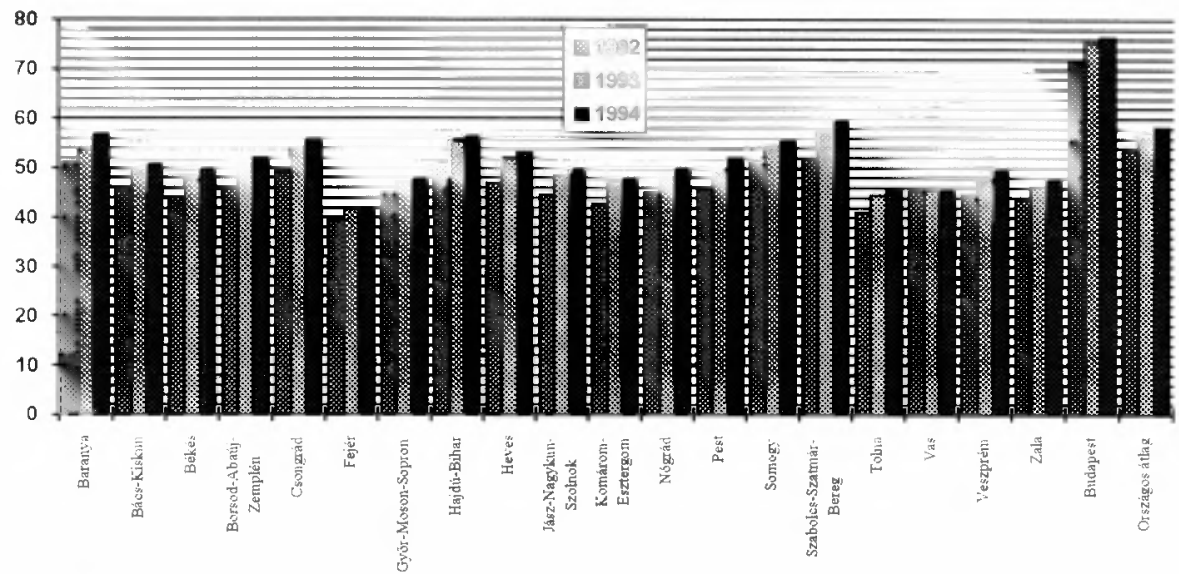

Forrás: Megyei statisztikai évkönyvek, KSH, 1994

\section{2. ÁBRA}

A fejlett üzleti szolgáltatások aránya az összes szolgáltatáson belül Magyarország megyéiben (The share of qualified business services inside the service sector by counties, \%)

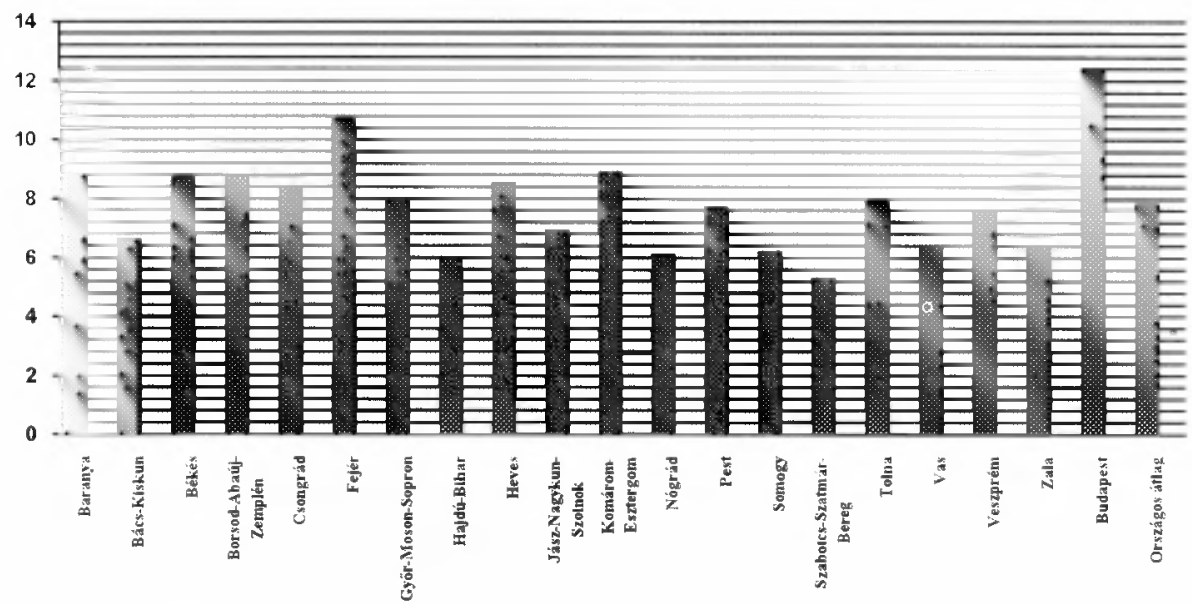

Forrás: Megyei statisztikai évkönyvek, KSH, 1994.

Megiegyzés: a statisztikai évkönyvek ágazati felosztásában a $G$ és $O$ ágazali kódszámok közé eső tevékenységek tartoznak a szolgáltatások körébe. Közülük mindössze kettö (a K. ṕnzzügvi

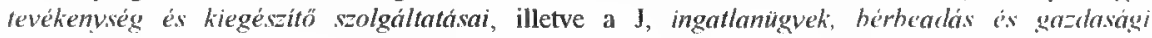
tevékenvé́gé segitö szolgáltatás) tekinthetö fejlett üzleti szolgáltatásnak. A fẹilcul nyuganti államokban az adatgyüjtés ennél részletesebb bontással történik (például az. Egycsült Királysíggban a piackutatásra, a vállalatvezetési tanácsadásra stb. külön adatok állnak rendelke`ćsrc). 


\section{Összefoglalás}

A modern társadalmakban mind fontosabbá váló szolgáltatások vagy tercier szektor nemcsak a foglalkoztatásban és a hazai össztermék előállításában való magas részesedése miatt érdemel megkülönböztetett figyelmet, hanem azért is, mert a fejlett szolgáltatások egyre inkább a regionális fejlődés, az egyes régiók gazdasági versenyképességének alapvető feltételét jelentik. A fejlett gazdaságszerkezettel rendelkezỏ országok tapasztalatai azt bizonyítják, hogy a kiemelkedő fejlődési ütemet mutató régiókban a gazdasági növekedés hagyományos motorja, a feldolgozóipar mellett, azzal összefonódva az üzleti szolgáltatások egyre jelentősebb szerepet játszanak. A személyes vagy háztartási, illetve a tisztán közösségi szolgáltatások a legfontosabb termelési tényezö, az emberi eröforrások vonzásának vagy megtartásának fontos eszközei.

A szolgáltatások nemcsak elösegítik egy adott terület gazdasági fejlỏdését, hanem szívesen telepednek is le a vonzó gazdasági környezettel rendelkező területeken, ami azok további erősödéséhez és a gyengébb gazdaságszerkezettel bíró régiók leszakadásához vezethet. Ennek megakadályozása egy tervszerü, átfogó regionális politika feladata, csakúgy, mint a belső fejlesztési erőforrások mobilizálása, illetve a külső forrásbevonás.

A gyengébb gazdaságszerkezettel rendelkezö régiók belső tartalékai nem mindig elégségesek a gazdasági struktúra modernizálására, a technológiai innovációk átvételére. Külső erőforrások bevonása viszont aligha képzelhetó el hatékony segítség, érdekképviselet és befolyás nélkül. A mai magyar gyakorlatban ezt a funkciót az önkormányzatok látják el, de általában nem a lehetséges és szükséges hatékonysággal. Gond emellett az is, hogy sok régióban nincs olyan szervezet, amely a modern gazdaság legfontosabb „árucikkét”, az információt összegyüjtené, feldolgozná és a régió gazdasági szereplöinek rendelkezésére bocsátaná. Ezek a hiányosságok egyrészt a fejlödés gátját jelentik, ugyanakkor jelzik a lehetséges megoldás, a felzárkózás irányait is.

\section{Jegyzetek}

További, elterjedt elnevezései a szolgáltatói társadalomnak: „harmadik hullám” (az első a gyüjtőgető, vadászó, halászó életmódról a mezögazdasági termelésre való áttérés volt, a második hullám az ipari forradalom), információs vagy tudás-társadalom, „posztfordista” vagy ,posztmodern” társadalom. William J. Coffrey és James J. McRae a "második”, avagy ,nem ipari forradalomról” beszél, amikor az ipar dominanciáját a szolgáltatások vezető szerepe váltja fel (Coffey, W. J. és McRae, J. J., 1989).

2 A kelet-közép-európai szocialista országokban a marx-i nézet vált uralkodóvá, ennek megfelelően a tercier szektor „nem termelékeny” gazdasági tevékenységként háttérbe szorult. Mára ez a nézet túlhaladottá vált. A modern marxisták már számos szolgáltatást külơnbơztetnek meg: kisegítő- vagy elökészítö munkát (amely az egyes termékhez kapcsolódik); az anyagok áramlásához kapcsolódó tevékenységek; az irányítás 'és a munkaeró újratermelése.

${ }^{3}$ Ezek a "tisztán közösségi szolgáltatások" egyébként egy fontos tulajdonságukban eltérnek a tipikus szolgáltatásoktól, nevezetesen abban, hogy a társadalom egészét szolgálják, nem mutatható ki egyértelmüen és személy szerint, hogy ki a fogyasztó, aki igy nyilván nem is vesz részt aktivan a szolgáltatás létrehozásában

\section{Irodalom}

Bell D. (1973) The Coming of the Post-Industrial Society. New York, Basic Books, Heinemann, London.

Bryson J.-Keeble D.-Wood P. (1993) The Creation, Location and Growth of Small Business Service Firms in the United Kingdom. In: Daniels, P. - Illeris, S. - BONAMY, J--Philippe J. (Eds.): The Geography of Services. Frank Cass \& Co., London. 118-131. o. 
Cappellin R. (1995) Regional Embeddedness and International Integration: The Case of SME's in North Italy. Előadás a Janus Pannonius Tudományegyetem Terület- és Településfejlesztési Szakán az MTA RKK Dunántúli Tudományos Intézetében. Kézirat.

Cappellin R. (1993) A termelő szolgáltatások technológiai változásai és teruleti terjedésuk. In: Horváth Gy. (szerk.): Régiók és városok az olasz modernizációban. MTA Regionális Kutatások Központja, Pécs. Régiók Európája, 1. 293-305. o.

Coffey W. J.-McRae J. J. (1989) Service Industries and Regional Development. The Institute for Research Public Policy, Halifax.

Gazdaságpolitikai Kisszótár.( (1966) Szerk.: Földes István. Kossuth Könyvkiadó, Budapest

Gzdaságpolitikai Kisszótár (I976). Szerk.: Gyenis János. Kossuth Könyvkiadó, Budapest

Gazdaságpolitikai Kisszótár (1983) Szerk.: Varsányi Zsuzsa. Kossuth Könyvkiadó, Budapest

Horváth Gy:: A Dél-Dunántúl nemzetközi versenyképességének elöfeltétele, a technológiai megújulás. In: Tér és Tár sadalom, 1994. 1-2, 37-58. o.

Illeris S. (1989) Services and Regions in Europe. ESCS-EEC-EAEC, Brussels-Luxembourg

Illeris S.-Philippe J. (1993) The Role of Services in Regional Economic Growth. In: Daniels, P. - Illeris, S. Bonamy, J. - Philippe, J. (Eds.): The Geography of Services. Frank Cass \& Co., London.. 3-10. 0.

Illeris S.(1994) Essays on Regional Development in Europe. Department of Geography and International Development Studies, Roskilde University

Illeris S.: Services and Regional Development. Elöadás a Janus Pannonius Tudományegyetem Terület- és Településfejlesztési Szakán az MTA RKK Dunántúli Tudományos Intézetében. Pécs, 1996. március 21.

Közgazdasági ABC.(1973) Szerk.: Muraközy Tamás-Zánkai G. Közgazdasági és Jogi Könyvkiadó, Budapest

Közgazdasági ABC mezögazdáknak.(1967) Szerk:: Muraközy Tamás - Varga Lajos - Nagy Lajos.

Mezógazdasági Könyvkiadó, Budapest

Közgazdasági Kislexikon.(1987) Szerk.: Varsányi Zsuzsa. Kossuth Könyvkiadó, Budapest

Longman Dictionary of Business English. ( 1993) Ed.: J. H. Adam. Akadémiai Kiadó, Budapest

Macmillan Dictionary of Modern Economics (A modern közgazdaságtan ismerettára). (1993) Szerk.: David W.

Pearce. Közgazdasági és Jogi Könyvkiadó, Budapest

Magyar Értelmezỏ Kéziszótár.(1982) Akadémiai Könyvkiadó, Budapest

Pálos I.-Arányi E. (1980) Szolgáltatások Magyarországon. Közgazdasági és Jogi Könyvkiadó, Budapest.

Senn L. (1993) Service Activities, Urban Hierarchy and Cumulative Growth. In: Daniels P.-llleris S.-Bonamy J.-Philippe J. (Eds.); The Geography of Services. Frank Cass \& Co., London. 11-22. o.

Soy A. (1994) Business Services and Regional Development. In: Hajdú, Z. - Horváth, Gy. (Eds.): European

Challenges and Hungarian Responses in Regional Policy. Pécs, Centre for Regional Studies. 273-282. 0.

Világgazdasági Kisszótár.(1994) Szerk.: Varsányi Zsuzsa. Kossuth Könyvkiadó, Budapest

\section{Abstract}

On the classical view, the role of the service sector in the economy is not very important, they don't produce new value, but consume the products, made by the other sectors, like parasite. On the 30-ies, some researcher began to attrack the attention, that as they society got richer, the people spend more money to services. The new working places were created most in the service sector, instead of the manufacturing.

The research of the service sector concentrated mostly on final consumption, to study the services offered for the households. On the second part of the 80-es the attention turned to the productive services, these are so companion services, which are consumed in the commodity production and consumer services, too.

The observations of the most developed countries show, that beside the manufactoring the classical engine of the economic development - to interweaved with it, the business services play more and more important role in the regional development, in that regions, which show outstanding achievment of developing accelerance. The personal or household, and the clearly common services become a very important device to attract and to protect the human resources - the most important production factor. 